\title{
Regeneração in vitro de Passiflora miniata Mast $^{(1)}$
}

\author{
PAULA PINHEIRO DE CARVALHO(2); CAMILA APARECIDA ANTONIAZZI(2); NAYARA TAYANE DA SILVA (2); \\ ANDRÉIA IZABEL MIKOSVKI (2), ILIO FEALHO DE CARVALHO(3); MAURECILNE LEMES DA SILVA CARVALHO(3)
}

\begin{abstract}
RESUMO
Passiflora miniata é uma espécie silvestre nativa da Amazônica Meridional, com potencial ornamental devido à beleza de suas flores de coloração vermelha intensa. Relatos na literatura sobre a espécie ainda são insipientes. O objetivo do presente estudo foi induzir a regeneração de novo pela via organogênica a partir de embriões zigóticos maduros de $P$. miniata. Os embriões zigóticos foram isolados e cultivados no meio de MS com a adição dos reguladores de crescimento 6-Benziladenine (BA), Thidiazuron (TDZ) e Cinetina (CIN). A regeneração de novo nos embriões zigóticos ocorreu de forma direta e/ou indireta. Um percentual de $80 \%$ dos explantes cultivados na presença de BA apresentaram organogênese pela via direta e 20\% pela indireta, com TDZ $60 \%$ foram regenerados pela via direta e $40 \%$ pela indireta. Já nos tratamentos com CIN 58\% do explantes apresentaram regeneração por organogênese direta e $42 \%$ pela indireta. O desenvolvimento dos primórdios das brotações iniciou-se com a formação das estruturas organogênicas que posteriormente se diferenciaram em multibrotações. As maiores médias no número de brotos produzidos foram na concentração de $0,75 \mathrm{mg} \mathrm{L}^{-1}$ de BA com 40,0 de brotos por explantes, sendo TDZ e CIN na concentração de $0,50 \mathrm{mg} \mathrm{L}^{-1}$ com média de 7,2 e 3,6, respectivamente.
\end{abstract}

Palavras chaves: Passiflora miniata, Maracujá Amazônico, Embrião zigótico, Organogênese.

\begin{abstract}
In vitro regeneration of Passiflora miniata Mast

Passiflora miniata is a wild species native to the Southern Amazon, with ornamental potential due to the beauty of its flowers of intense red coloration. Reports in the literature about the species are still insipid. The aim of the present study was to induce the regeneration of $P$. miniata by the de novo organogenesis from mature zygotic embryos. The zygotic embryos were isolated and cultivated into the MS medium with the addition of 6-Benzyladenine (BA), Thidiazuron (TDZ) and Kinetin (KIN) growth regulators. The de novo regeneration from the zygotic embryos occurred directly and indirectly. A percentage of $80 \%$ of the explants cultivated in the presence of BA had direct organogenesis and $20 \%$ by the indirect way, with TDZ $60 \%$ were regenerated by the direct and $40 \%$ by the indirect way. Regarding the treatments with KIN, $58 \%$ of the explants had regeneration by direct and $42 \%$ by the indirect organogenesis. The development of shoot primordia initiated with the formation of organogenic structures that later differentiated into multi-shoots. The highest mean number of shoots (40.0 shoots per explants) was obtained on $0.75 \mathrm{mg} \mathrm{L}^{-1}$ BA. Conversely, using $0.50 \mathrm{mg} \mathrm{L}^{-1} \mathrm{TDZ}$ or KIN, the highest number of shoots were 7.2 and 3.6, respectively.
\end{abstract}

Keywords: Passiflora miniata, Amazonic Passionfruit, Zygotic embryo, Organogenesis.

\section{INTRODUÇÃO}

A família Passifloraceae é constituída de 20 gêneros e cerca de 630 espécies (CERVI, 2006; AMORIM et al., 2013). O gênero Passiflora possui cerca de 400 a 530 espécies, das quais de 150 a 200 são originárias do Brasil que é considerado um importante centro de diversidade do gênero (ABREU et al., 2009; PIPINO et al., 2010; SILVA et al., 2011). Muitas espécies de Passiflora podem ser utilizadas como alimento, remédios e suas flores são cultivadas como ornamento e muitas delas com finalidades múltiplas (ABREU et al., 2009).

Atualmente espécies de Passiflora ganharam atenção como plantas ornamentais, principalmente devido à beleza e exuberância de suas flores, com grande variação de coloração forte e brilhante e algumas outras de coloração tênue e suave (MONTERO et al., 2013). O potencial ornamental dos maracujazeiros é praticamente inexplorado no Brasil, apesar de ser considerado centro de origem e de diversidade. Nos países do hemisfério norte já foram produzidos e registrados mais de 400 híbridos para fins ornamentais (PEIXOTO, 2005).

Passiflora miniata Mast. é uma espécie silvestre nativa da Amazônica Meridional brasileira, podendo também ser também encontrada na Bolívia, Colômbia, Peru, assim como Venezuela e Guianas (LIM, 2012). Tem sido extensivamente cultivada de forma errônea como Passiflora coccinea, devido às características similares das flores de coloração vermelho intenso (VANDERPLANK, 2006). Estudos que envolvem a regeneração in vitro de $P$. miniata

DOI: http://dx.doi.org/10.14295/oh.v23i1.965

(1) Received in 07/09/2016 and approved in 23/02/2017

(2) Universidade do Estado de Mato Grosso (UNEMAT), Campus de Tangará da Serra-MT, Brasil.

(3) Departamento de Ciências Biológicas/ Universidade do Estado de Mato Grosso, Campus de Tangará da Serra-MT, Brasil.* Autor correspondente: maurecilne@gmail.com 
somente foram relatados no estabelecimento de protocolo de embriogênese somática (FERREIRA et al., 2015).

As técnicas aplicadas para a regeneração de maracujazeiros por meio da cultura de tecidos aumentaram exponencialmente em todo o mundo, utilizando-se de diferentes tipos de explantes como, discos foliares em $P$. edulis (AMUGUNE et al., 1993), segmentos intermodais em $P$. edulis (BIASI et al., 2000), radiculares em $P$. cincinnata e $P$. edulis (SILVA et al., 2011), foliares de $P$. alata (PACHECO et al., 2012), em P. suberosa a partir de segmentos nodais, intermodais e seguimentos foliares (GARCIA et al., 2011), explantes hipocotiledonares em $P$. setacea (VIEIRA et al., 2014), nodais em $P$. foetida (ANAND et al., 2012; SHEKHAWAT et al., 2015), hipocotiledonares e radiculares provenientes de $P$. edulis (ROCHA et al., 2016) e embrião zigótico (ROCHA et al., 2015).

A regeneração de novo refere-se à formação de brotos e raízes a partir dos explantes cultivados em condições in vitro sendo influenciado principalmente pelo tipo de explante e a combinação dos reguladores de crescimento (SKOOG e MILLER 1957; DUCLERCQ et al., 2011; XU e HUANG, 2014). A sinalização dos reguladores de crescimento leva a redefinição do padrão de expressão de genes, da proliferação e diferenciação celular até o desenvolvimento de um órgão na planta (DE KLERK et al., 1997).

Devido ao potencial ornamental da espécie de maracujazeiro amazônico e da escassez de estudos sobre o seu cultivo in vitro, o trabalho teve como objetivo induzir a regeneração de novo pela via organogênica de $P$. miniata a partir de embriões zigóticos maduros.

\section{MATERIAL E MÉTODOS}

Frutos maduros de $P$. miniata foram coletados em plantio particular no município de Tangará da Serra/ MT. As sementes após extração manual foram lavadas e friccionadas em peneira até a total eliminação do arilo e da mucilagem. Em seguida foram colocadas sobre papel, à sombra, em temperatura ambiente por um período de sete dias para secagem. Após o tegumento das sementes foram removidos com o auxílio de uma mini morsa.

Sob condições assépticas em câmara de fluxo laminar as sementes foram desinfestadas em álcool a $70 \%\left(\mathrm{v} \mathrm{v}^{-1}\right)$ por dois minutos, e lavadas com água deionizada e esterilizada, seguido pela imersão em solução de hipoclorito de sódio comercial a 2,5\% $\left(\mathrm{v} \mathrm{v} \mathrm{v}^{-1}\right)$, acrescido de três gotas de Tween 20 por $100 \mathrm{~mL}$ de solução durante 15 minutos e submetidas a quatro lavagens com água destilada e esterilizada.

As sementes de P. miniata foram mantidas por 12 horas em água destilada e esterilizada para facilitar a remoção do endosperma e o isolamento dos embriões zigóticos. Após, os embriões foram inoculados em meio MS (MURASHIGE e SKOOG, 1962) contendo $0,3 \%\left(\mathrm{p} \mathrm{v}^{-1}\right)$ de sacarose, $0,01 \%$ $\left(\mathrm{p} \mathrm{v}^{-1}\right)$ de mio-inositol, e gelificado com ágar a $0,8 \%\left(\mathrm{p} \mathrm{v}^{-1}\right)$. Os reguladores de crescimento utilizados para a indução de organogênese foram 6-Benziladenina (BA); Thidiazuron (TDZ) e a Cinetina (CIN) nas concentrações de 0,$50 ; 0,75$; 1,$0 ; 1,25 ; 1,50 ; 1,75$ e $2,0 \mathrm{mg} \mathrm{L}^{-1}$, além do tratamento controle. $\mathrm{O}$ pH do meio foi ajustado a 5,7 $\pm 0,1$, em seguida, autoclavados por 20 minutos, $121{ }^{\circ} \mathrm{C}$ e $1,1 \mathrm{~atm}$ de pressão.

$\mathrm{O}$ meio foi vertido em placas de Petri de poliestireno cristal de 90 × $15 \mathrm{~mm}$ estéreis em alíquotas de 25 a 30 $\mathrm{mL}$, sendo essas seladas com filme de policloreto de vinila - PVC esticável de 9-10 $\mu \mathrm{m}$ de poro. As culturas foram mantidas em sala de cultivo, sob irradiância de fótons de $36 \mu \mathrm{mol} \mathrm{m} \mathrm{m}^{-2} \mathrm{~s}^{-1}$, temperatura de $25^{\circ} \mathrm{C} \pm 2$ e fotoperíodo de 16 horas. Após 30 dias de cultivo as brotações com aproximadamente $1 \mathrm{~cm}$ foram isoladas e cultivadas no meio de MS em tubos de ensaios para o alongamento e enraizamento sob irradiância durante 30 dias.

O delineamento experimental utilizado foi o inteiramente casualizado, em arranjo fatorial duplo de $3 \times 7$ (regulador de crescimento $x$ concentrações dos reguladores) e o controle, totalizando 22 tratamentos, com cinco repetições e cinco explante por placa. Os parâmetros morfogênicos avaliados foram o percentual de organogênese direta e indireta para cada regulador de crescimento, explantes com resposta e sem resposta morfogênica e a média de produção de brotações adventícias.

Os dados foram submetidos à análise de variância (ANOVA) e a diferença entre as médias dos tratamentos foram comparadas pelo teste Tukey a 5\% de probabilidade pelo software Sisvar ${ }^{\circledR}$, versão 5.6 (FERREIRA, 2011).

\section{RESULTADOS E DISCUSSÃO}

A espécie $P$. miniata ainda é pouco estudada e apresenta potencial ornamental devido à beleza de suas flores e frutos (Figura 1A e 1B) e relatos na literatura sobre a regeneração de novo in vitro a partir da organogênese ainda não foram descritos. 


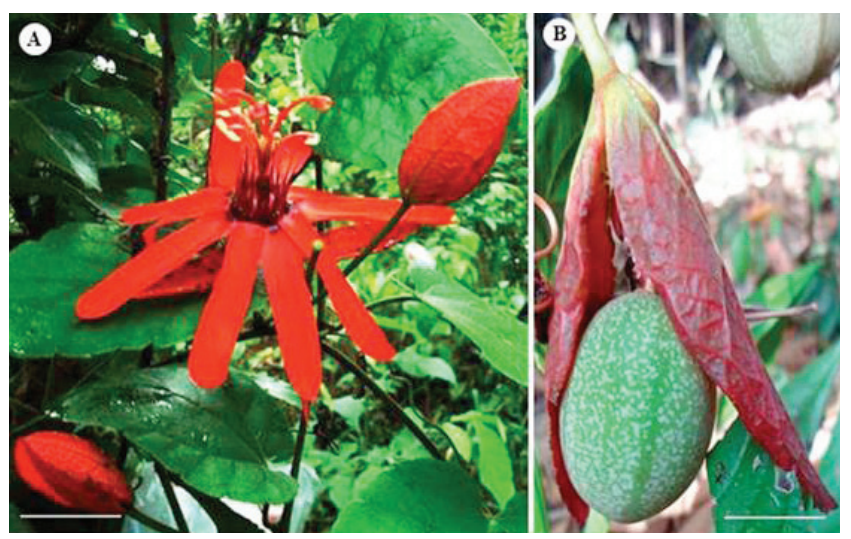

Figura 1. A-Flor; B-Fruto de P. miniata (Bars. A 45mm; B 20mm)

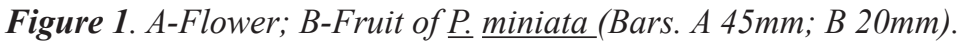

A regeneração de $P$. miniata a partir dos embriões zigóticos ocorreu de forma direta (Figura 2A) e indireta (Figura 2B). Após 20 dias de cultivo pôde-se observar o desenvolvimento de regiões apresentando estruturas organogênicas que posteriormente se diferenciaram em multibrotações (Figura 2C e 2D).
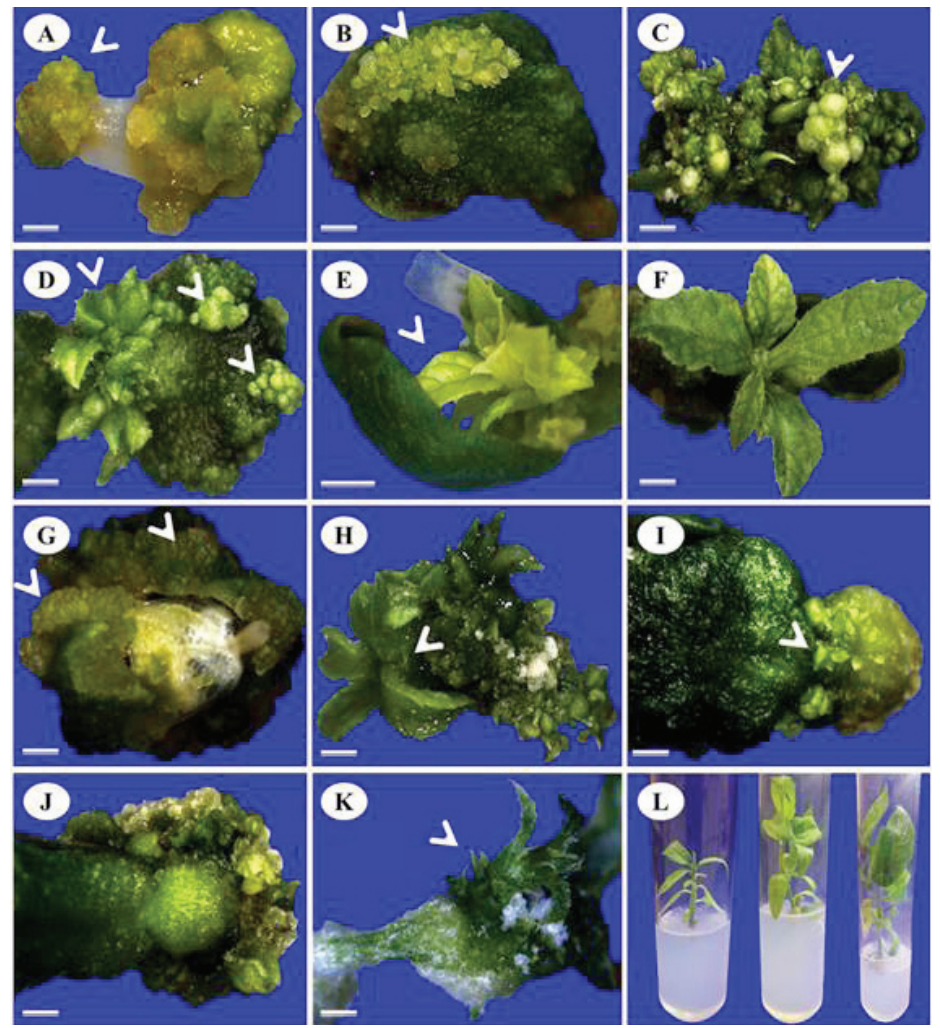

Figura 2. Regeneração in vitro a partir de embriões zigóticos de $P$. miniata aos 30 dias de cultivo.

A- Organogênese indireta (seta); B- Organogênese direta (seta); C-D- Estruturas organogênicas e desenvolvimento de brotos (setas); E-F- Organogênese direta 0,75 e 1,0 $\mathrm{mgL}^{-1} \mathrm{BA}$ (seta) e brotos com folhas expandidas;

G-H - Estruturas organogênicas e a diferenciação de brotações em meio com TDZ (seta);

I-J - Primórdios de brotos desenvolvidos em meio com a presença cinetina (setas);

$\mathrm{K}$ - Broto produzido na ausência de regulador de crescimento no tratamento controle; L - Planta regeneradas e alongadas in vitro após 30 dias de cultivo in vitro. A-B-C-F (Bars $=35 \mu \mathrm{m}) ; \mathrm{D}(\mathrm{Bar}=25 \mu \mathrm{m})$; E-I-K-L

$($ Bars $=80 \mu \mathrm{m}) ; \mathrm{G}(\mathrm{Bar}=55 \mu \mathrm{m}) ; \mathrm{H}-\mathrm{J}($ Bars $=60 \mu \mathrm{m}) ; \mathrm{L}(\mathrm{Bar}=10 \mathrm{~mm})$.

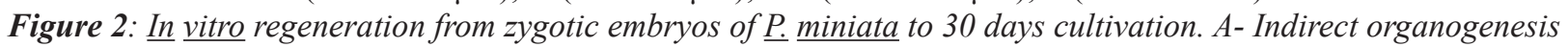
(arrow); $B$-Direct organogenesis (arrow); $C$-D - Organogenesis structures and development shoots (arrows); $E-F$ - Direct organogenesis 0.75 and $1.0 \mathrm{mgL}^{-1} B A$ (arrows) and shoots with expanded leaves; $G$ - $H$ - Organogenic structures and differentiation of shoots in medium with TDZ; I-J - Early shoots developed in medium with the kinetin

(arrow); $K$-Shoots produced in the absence of growth regulator in the control treatment (arrows);

Regenerated plants and lengthened after 30 days in vitro cultivation. $A-B-C-F(B a r s=35 \mu \mathrm{m})$; $D($ Bar $=25 \mu \mathrm{m}) ; E-I-K-L($ Bars $=80 \mu \mathrm{m}) ; G($ Bar $=55 \mu \mathrm{m}) ; \mathrm{H}-J($ Bars $=60 \mu \mathrm{m}) ; L($ Bar $=10 \mathrm{~mm})$. 
Embriões zigóticos cultivados na presença de BA responderam com um percentual de $80 \%$ de organogênese pela via direta e $20 \%$ pela indireta (Figura 3). A organogênese é o sistema de regeneração que resulta na formação de uma estrutura unipolar, denominada de eixos caulinares. As gemas podem originar-se do tecido do explante com conexão vascular, caracterizando a organogênese direta, ou por meio intermediário da formação de células desdiferenciadas, denominada de calos, caracterizando a rota da organogênese indireta (GEORGE, 2008; MOURA et al., 2001; NICK, 2014).

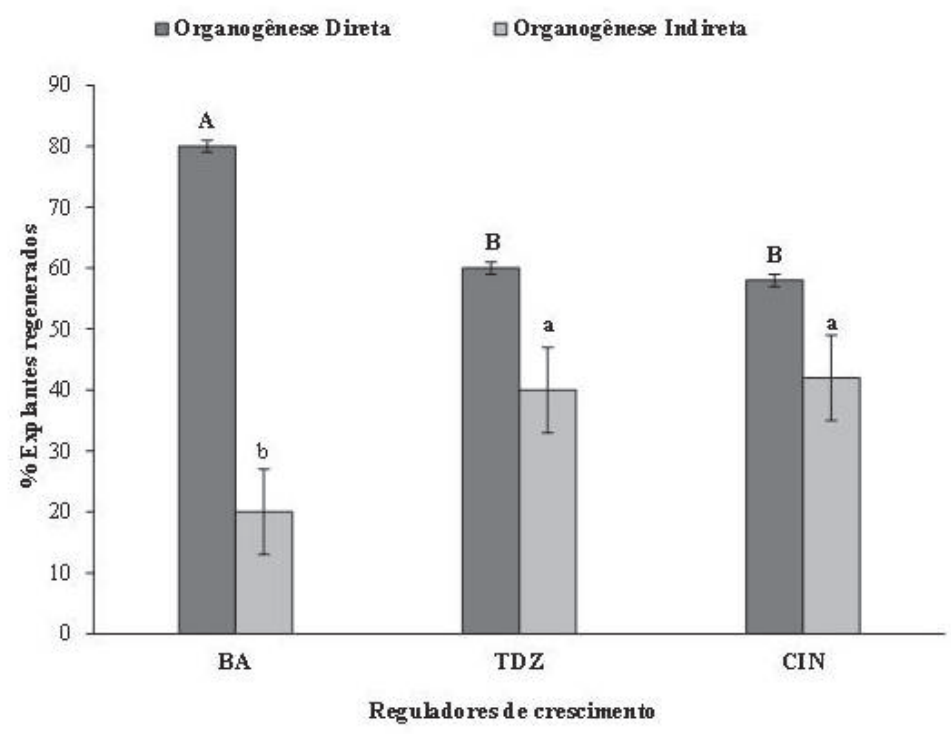

Figura 3. Organogênese direta em indireta a partir de embriões zigóticos após 30 dias de cultivo in vitro na presença das citocininas BA, TDZ e CIN.

Figure 3. Direct and indirect organogenesis from zygotic embryos after 30 days in vitro cultivation in the presence of cytokinins BA, TDZ and KIN.

O desenvolvimento de um novo propágulo refere-se à formação de brotos ou raízes cultivados sob condições in vitro, sendo que o processo de organogênese pode ser influenciado principalmente pelo tipo de explantes e pelo uso de reguladores de crescimento adicionados ao meio de cultura (SKOOG e MILLER, 1957; ROCHA et al., 2016).

Aos 30 dias de cultivo dos embriões foi possível observar que na variável número de explante com resposta, não houve diferença significativa dentre as concentrações de cada regulador de crescimento. Entretanto, ao comparar cada tratamento entre os reguladores observou-se a ocorrência de diferença entre as respostas morfogênicas correspondentes as concentrações de 0,$75 ; 1,0$; e $1,50 \mathrm{mg} \mathrm{L}^{-1}$ de BA, com média de 4,4 explantes com resposta morfogênica. Tal resposta foi caracterizada pelo intumescimento do embrião e o desenvolvimento de estruturas organogênicas de coloração amarelo-esverdeado (Figuras 2E e 2F). As estruturas organogênicas foram observadas no início do desenvolvimento até a diferenciação das brotações de forma direta.

Em relação a variável número de brotos foi verificado a ocorrência de interação nos tratamentos entre o uso de BA com os reguladores de crescimento TDZ e CIN. Sendo que durante a organogênese, o uso de BA em baixas concentrações promoveu a regeneração de maior número de brotos (Tabela 1). 
Tabela 1. Média de explantes com e sem resposta morfogênica e o número de brotos produzidos a partir de embriões zigóticos como fonte de explante em $P$. miniata aos 30 dias de cultivo in vitro.

Table 1: Means of explants with and without morphogenic response and the number of shoots produced from the zygotic

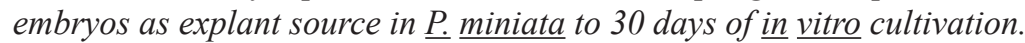

\begin{tabular}{|c|c|c|c|c|c|c|c|c|c|}
\hline \multirow[t]{3}{*}{$\begin{array}{l}\text { Tratamentos } \\
\qquad\left(\mathrm{mg} \mathrm{L}^{-1}\right)\end{array}$} & \multicolumn{9}{|c|}{ Embriões zigóticos } \\
\hline & \multicolumn{3}{|c|}{ Explantes com resposta } & \multicolumn{3}{|c|}{ Explantes sem resposta } & \multicolumn{3}{|c|}{ Média do número de Brotos } \\
\hline & BA & $\mathrm{TDZ}$ & $\mathrm{CIN}$ & BA & TDZ & $\mathrm{CIN}$ & BA & TDZ & $\mathrm{CIN}$ \\
\hline Controle & $3,0^{\mathrm{Aa}}$ & $3,0^{\mathrm{Aa}}$ & $3,0^{\mathrm{Aa}}$ & $2,0^{\mathrm{Aa}}$ & $2,0^{\mathrm{Aa}}$ & $2,0^{\mathrm{Aa}}$ & $3,0^{\mathrm{BCa}}$ & $3,0^{\mathrm{Aa}}$ & $3,0^{\text {Аa }}$ \\
\hline 0,50 & $3,4^{\mathrm{Aa}}$ & $3,6^{\mathrm{Aa}}$ & $3,4^{\mathrm{Aa}}$ & $1,6^{\mathrm{Aa}}$ & $1,4^{\mathrm{Aa}}$ & $1,6^{\mathrm{Aa}}$ & $17,2^{\text {ва }}$ & $7,2^{\text {Аa }}$ & $3,6^{\text {Aa }}$ \\
\hline 0,75 & $4,4^{\text {Аа }}$ & $4,4^{\mathrm{Aa}}$ & $3,0^{\mathrm{Ab}}$ & $0,6^{\mathrm{Ab}}$ & $0,6^{\mathrm{Ab}}$ & $2,0^{\mathrm{Aa}}$ & $40,0^{\mathrm{Aa}}$ & $1,4^{\mathrm{Ab}}$ & $1,6^{\mathrm{Ab}}$ \\
\hline 1,00 & $4,4^{\mathrm{Aa}}$ & $4,8^{\mathrm{Aa}}$ & $3,0^{\mathrm{Ab}}$ & $0,6^{\mathrm{Ab}}$ & $0,2^{\mathrm{Ab}}$ & $2,0^{\mathrm{Aa}}$ & $26,4^{\mathrm{ABa}}$ & $2,6^{\mathrm{Ab}}$ & $1,2^{\mathrm{Ab}}$ \\
\hline 1,25 & $3,2^{\mathrm{Aa}}$ & 4,4 Aa & $4,0^{\mathrm{Aa}}$ & $1,8^{\mathrm{Aa}}$ & $0,6^{\mathrm{Aa}}$ & $1,0^{\mathrm{Aa}}$ & $18,2^{\mathrm{ABa}}$ & $2,6^{\mathrm{Aa}}$ & $2,4^{\mathrm{Aa}}$ \\
\hline 1,50 & $4,4^{\mathrm{Aa}}$ & $4,0^{\mathrm{Aa}}$ & $2,6^{\mathrm{Ab}}$ & $0,6^{\mathrm{Ab}}$ & $1,0^{\mathrm{Ab}}$ & $2,4^{\mathrm{Aa}}$ & $27,2^{\mathrm{ABa}}$ & $0,8^{\mathrm{Ab}}$ & $0,6^{\mathrm{Ab}}$ \\
\hline 1,75 & $4,2^{\mathrm{Aa}}$ & $3,2^{\mathrm{Aa}}$ & $3,6^{\mathrm{Aa}}$ & $0,8^{\mathrm{Ab}}$ & $1,8^{\mathrm{Ab}}$ & $1,4^{\mathrm{Ab}}$ & $10,6^{\mathrm{Ba}}$ & $0,0^{\mathrm{Aa}}$ & $1,6^{\mathrm{Aa}}$ \\
\hline 2,00 & $3,8^{\mathrm{Aab}}$ & $4,2^{\text {Aa }}$ & $2,6^{\mathrm{Ab}}$ & $1,4^{\mathrm{Aab}}$ & $0,8^{\mathrm{Ab}}$ & $2,4^{\mathrm{Aa}}$ & $31,0^{\mathrm{ABa}}$ & $0,0^{\mathrm{Ab}}$ & $0,8^{\mathrm{Ab}}$ \\
\hline C.V(\%) & \multicolumn{3}{|c|}{25,68} & \multicolumn{3}{|c|}{74,72} & \multicolumn{3}{|c|}{46,69} \\
\hline Erro Padrão & \multicolumn{3}{|c|}{0,42} & \multicolumn{3}{|c|}{0,43} & \multicolumn{3}{|c|}{0,25} \\
\hline
\end{tabular}

*Médias seguidas pela mesma letra na coluna não diferem estatisticamente entre si pelo teste de Tukey a $(P<0.05)$.

*Means followed by the same letter in the column do not differ statistically between themselves by Tukey test $(P<0.05)$.

$\mathrm{O}$ regulador de crescimento comumente utilizado na regeneração de novo pela via organogênica em Passiflora é o BA, que induz a manutenção e a diferenciação da parte aérea e de meristemas apicais e radiculares (SILVA et al., 2011; ROCHA et al., 2012; ROSA e DORNELAS, 2012; OTONI et al., 2013). Já o TDZ e a CIN são utilizados para a regeneração em Passiflora em baixas concentrações (PINTO et al., 2010; GARCIA et al., 2011).

Os embriões cultivados no meio com TDZ apresentaram o desenvolvimento de primórdios das brotações em toda a região dos cotilédones (Figura $2 \mathrm{G}$ ). No desenvolvimento mais tardio, essas estruturas resultaram na formação de um eixo unipolar já com a formação dos primórdios foliares (Figura 2H). A produção de brotos entre os tratamentos com TDZ, não apresentaram diferença estatística entre si, sendo que a maior média de 7,2 brotos foi observada na presença de $0,50 \mathrm{mg} \mathrm{L}^{-1}$. O aumento nas concentrações de TDZ, aparentemente, inibe o desenvolvimento das brotações.

O TDZ é um composto substituído por fenilureia e seu papel durante a morfogênese está intimamente relacionado com o metabolismo dos reguladores endógenos de crescimento, sendo mais biologicamente ativo do que BA e concentrações mais baixas são necessárias especialmente durante a micropropagação (MOK et al., 1987, MURTHY et al., 1998).

Quando cultivados na presença com CIN na concentração de $0,50 \mathrm{mg} \mathrm{L}^{-1}$, os embriões responderam com a maior média de 3,6 de brotos produzidos, seguida de 2,4 no tratamento com $1,25 \mathrm{mg} \mathrm{L}^{-1}$, e não foi observado o alongamento das brotações (Figuras 2I e 2J). Isso demonstra que este regulador de crescimento induz a regeneração pela via organogênica utilizando-se de embriões zigóticos, mas, é necessário a etapa intermediária para o alongamento das brotações obtidas para a espécie $P$. miniata.

No processo de regeneração pela via organogênica do gênero Passiflora, comumente são utilizados como fonte de explantes, folha, hipocótilo e o seguimento internodal (ROCHA et al., 2012; VIEIRA et al., 2014; VINOD e JAYABALAN, 2015; CARVALHO et al., 2015). Já o uso de embriões zigóticos é mais empregado na regeneração pela via embriogênica (SILVA et al., 2009; PINTO et al., 2011).

Rocha et al. (2015) utilizando-se de embriões zigóticos para a regeneração pelas vias organogênica e embriogênica relatam que este tipo de explante pode responder no desenvolvimento de brotações e/ou embriões somáticos. Além disso, as respostas são dependentes das concentrações dos reguladores de crescimento disponíveis no meio de cultivo. Já Elhiti e Stasolla (2011) relatam que os embriões de modo geral, são fontes de células juvenis, em constante divisão mitótica, o que facilita o processo de regeneração.

O tratamento controle na ausência das citocininas respondeu com o desenvolvimento de uma média de 3,0 brotos por explante (Tabela 1) e já apresentavam primórdios foliares (Figura 2K). Através dos resultados obtidos os embriões zigóticos comprovou ser uma fonte alternativa de explante para a regeneração pela via organogênica e a obtenção de planta de $P$. miniata (Figura 2L) após 30 dias de cultivo in vitro. 


\section{CONCLUSÃO}

A regeneração de novo da espécie silvestre $P$. miniata pela via organogênica utilizando-se de embriões zigóticos ocorre de forma direta e indireta. O regulador de crescimento BA demonstra maior efetividade na produção de brotações em relação às citocininas TDZ e CIN.

\section{AGRADECIMENTOS}

À Coordenação de Aperfeiçoamento de Pessoal de Nível Superior/CAPES, pela concessão da Bolsa de Mestrado, a Fundação de Amparo à Pesquisa do Estado de Mato Grosso/ FAPEMAT pelo financiamento e a Greiciele Farias da Silveira pela disponibilização das fotos de $P$. miniata.

\section{CONTRIBUIÇÃO DOS AUTORES}

CPP: Coleta dos dados, Análise e interpretação dos dados, elaboração do artigo. CAA: Análise e interpretação dos dados. NTS - Análise e interpretação dos dados. AIM: Análise e interpretação dos dados, elaboração e revisão critica do artigo. IFC: Aprovação final da versão a ser publicada, redação e revisão critica do artigo. MLSC: Concepção do trabalho, elaboração e revisão critica do artigo, aprovação final da versão a ser publicada.

\section{REFERÊNCIAS}

ABREU, P.P. Passion flower hybrids and their use in the ornamental plant market: perspectives for sustainable development with emphasis on Brazil. Euphytica, International Journal of Plant Breeding, v.166, n.3, p.307-315, 2009. DOI: http://sci-hub.cc/10.1007/s10681008-9835-x.

AMORIM, F.L.; SILVEIRA, P.T.S.; SILVA, G.V.; CAFIEIRO, C.S.P. Elaboração e aceitação sensorial de licor maracujá-do-mato com diferentes tipos de calda. Revista de Desenvolvimento e Inovação, v.1, n.1. p.8891, 2013. DOI: http://revista.ifro.edu.br/index.php/redi/ article/download/29/21.

AMUGUNE, N.O.; GOPALAN, H.N.B.; BYTEBIER, B. Leaf disc regeneration of passion fruit. African Crop Science Journal, v.1, n.2, p.99-104, 1993. DOI: http://www. ajol.info/index.php/acsj/article/viewFile/69896/57971.

ANAND, S.P.; JAYAKUMAR, E.; JEYACHANDRAN, R.; NANDAGOBALAN, V.; DOSS, A. Direct organogenesis of Passiflora foetida L. through nodal explants. Plant Tissue Culture and Biotechnology, v.22, n.1, p.87-91, 2012. DOI: http://www.banglajol.info/index.php/PTCB/ article/view/11266.

BIASI, L.A.; FALCO, M.C.; RODRIGUEZ, A.P.; MENDES, B.M.J. Organogenesis from internodal segments of yellow passion fruit. Scientia Agricola, v.57, n.4 p 661-665, 2000. DOI: http://dx.doi.org/10.1590/ S0103-90162000000400010.
CARVALHO, M.A.D.F.; PAIVA, R.; HERRERA, R.C.; ALVES, E.; CASTRO, E.M.D.; PAIVA, P.D.D.O.; VARGAS, D.P. Indução, análises morfológicas e ultraestruturais de calos de maracujazeiro nativo. Revista Ceres, v.62. n.4. p.340-346, 2015. DOI: http://dx.doi. org/10.1590/0034-737X201562040002

CERVI, A.C.O Gênero Passiflora L. (Passifloraceae) no Brasil, espécies descritas após o ano de 1950. Adumbrationes ad Summae Editionem, v.16, p.1-5, 2006. DOI: http://bibdigital.rjb.csic.es/PDF/Adumb_16.pdf.

DE KLERK, G.J.; ARNHOLDT-SCHMITT, B.; LIEBEREI, R.; NEUMANN, K.H. Regeneration of roots, shoots and embryos: physiological, biochemical and molecular aspects. Biologia Plantarum, v.39, n.1, p.53-66, 1997. DOI: http://10.1023/A:1000304922507

DUCLERCQ, J.; SANGWAN-NORREEL, B.; CATTEROU, M.; SANGWAN, R.S.; De novo shoot organogenesis: from art to science. Trends in Plant Science, v.16, n.11, p.597-606, 2011. DOI: 10.1016/j. tplants.2011.08.004.

ELHITI, M.; STASOLLA, C. Ectopic expression of the Brassica SHOOT MERISTEMLESS attenuates the deleterious effects of the auxin transport inhibitor TIBA on somatic embryo number and morphology. Plant Science, v.180, n.2, p.383-390, 2011. DOI: http://sci-hub. cc/10.1016/j.plantsci.2010.10.014

FERREIRA, D.F. Sisvar: a computer statistical analysis system. Ciência e Agrotecnologia, v.35, n.6, p.10391042, 2011. DOI: http://dx.doi.org/10.1590/S141370542011000600001

FERREIRA, D.A.T.; SATTLER, M.C.; CARVALHO, C.R.; CLARINDO, W.R. Embryogenic potential of immature zygotic embryos of Passiflora: a new advance for in vitro propagation without plant growth regulators. Plant Cell, Tissue and Organ Culture, v.122, n.3, p. 629-638, 2015. DOI: http://sci-hub.cc/10.1007/ s11240-015-0796-1

GARCIA, R.; PACHECO, G.; FALCÃO, E.; BORGES, G.; MANSUR, E. Influence of type of explant, plant growth regulators, salt composition of basal medium, and light on callogenesis and regeneration in Passiflora suberosa L. (Passifloraceae). Plant Cell, Tissue and Organ Culture, v.106, n.1, p.47-54, 2011. DOI: http://10.1007/s11240010-9892-4

GEORGE, E.F.; DAVIES, W. In: GEORGE, E.F., HALL, M.A., DE KLERK, G.J. (eds) Plant Propagation by Tissue Culture, 3rd ed. Springer, 2008, 479p.

LIM, T.K. Passiflora miniata. Edible Medicinal And NonMedicinal Plants: Volume 4, Fruits. 178 - 180p, 2012. 
MOK, M.C.; MOK, D.W.S.; TURNER, J.E.; MUJER, C.V. Biological and biochemical effects of cytokininactive phenylurea derivatives in tissue culture systems. Horticultural Science, v.22, n.6, p.1194-1197, 1987.

MONTERO, D.A.V.; MELETTI, L.M.M.; MARQUES, M.O.M. Fenologia do florescimento e características do perfume das flores de Passiflora quadrangularis L. (maracujá-melão). Revista Brasileira de Horticultura Ornamental, v.19, n.2, p.99-106, 2013. DOI: http://dx.doi. org/10.14295/rbho.v19i2.654.

MOURA, T.L.; DE ALMEIDA, W.A.B.; MADALENA, B.; MENDES, J.; FILHO, F.D.A.A.M. Organogênese in vitro de Citrus em função de concentrações de BAP e seccionamento do explante. Revista Brasileira de Fruticultura, v.23, n.2, p.240-245, 2001. http://dx.doi. org/10.1590/S0100-29452001000200007.

MURASHIGE, T.; SKOOG, F.A. A revised medium for rapid growth and bio assays with tobacco tissue cultures. Physiologia Plantarum, v.15, n.3, p.473-497, 1962. DOI: $\quad$ http://doi.wiley.com/10.1111/j.1399-3054.1962. tb08052.x

MURTHY, B.N.S.; MURCH, S.J.; SAXENA, P.K. Thidiazuron: A potent regulator of in vitro plant morphogenesis. In Vitro Cellular \& Developmental Biology - Plant, v.34, p.267-275, 1998. DOI:10.1007/ BF02822732.

NICK, P.; OPATRNY,Z. Applied Plant Cell Biology Cellular Tools and Approaches for Plant Biotechnology. Plant Cell Monographs, v.22, 481-485, 2014. DOI 10.1007/978-3642-41787-0

OTONI, W.C.; PAIM PINTO, D.L.; ROCHA, D.I.; VIEIRA, L.M.; DIAS, L.L.C.; SILVA, M.L.; SILVA, C.V.; LANI, E.R.G.; SILVA, L.C.; TANAKA, F.A.O. Organogenesis and somatic embryogenesis in passionfruit (Passifloras sp). In: ASLAM, J.; SRIVASTAVA, O.S.; SHARMA, M. P. (eds.) Somatic embryogenesis and gene expression. New Delhi; Narosa Publishing House, 2013, p.1-17.

PACHECO, G.; GARCIA, R.; LUGATO, D.; VIANNA, M.; MANSUR, E. Plant regeneration, callus induction and establishment of cell suspension cultures of Passiflora alata Curtis. Scientia Horticulturae, v.144, p.42-47, 2012. Doi: http://sci-hub.cc/10.1016/j.scienta.2012.06.022.

PEIXOTO, M. Problemas e perspectivas do maracujá ornamental. In: FALEIRO, F.G.; JUNQUEIRA, N.T.V.;

BRAGA, M.F. (eds.) Maracujá germoplasma e melhoramento genético. Planaltina, DF: Embrapa Cerrados, 2005, p. 458-462.
PINTO, A.P.C.; MONTEIRO-HARA, A.C.B.A.; STIPP, L.C.L.; MENDES, B.M.J. In vitro organogenesis of Passiflora alata. In Vitro Cellular and Developmental Biology-Plant, v.46, n.1, p. 28-33, 2010. DOI: http://sci-hub. cc/10.1007/s11627-009-9251-5

PINTO, D.L.P.; ALMEIDA, A.M.R.; RÊGO, M.M.; SILVA, M.L.; OLIVEIRA, E.J.; OTONI, W. C. Somatic embryogenesis from mature zygotic embryos of commercial passionfruit (Passiflora edulis Sims) genotypes. Plant Cell, Tissue and Organ Culture, v.107, n.3, p.521-530, 2011. DOI: http://sci-hub.cc/10.1007/s11240-011-0003-y

PIPINO, L.; BRAGLIA, L.; GIOVANNINI, A.; FASCELLA, G.; MERCURI, A. In vitro regeneration and multiplication of Passiflora hybrid "Guglielmo Betto". In: JAIN, S.M.; OCHATT, S.J. (eds.), Protocols for In Vitro Propagation of Ornamental Plants, Methods in Molecular Biology, v.588, p.153-162, 2010.

ROCHA, D.I.; VIEIRA, L.M.; TANAKA, F.A.O.; DA SILVA, L.C.; OTONI, W.C. Anatomical and ultrastructural analyses of in vitro organogenesis from root explants of commercial passion fruit (Passiflora edulis Sims). Plant Cell, Tissue and Organ Culture, v.111, n.1, p. 69-78, 2012. DOI: http://sci-hub.cc/10.1007/s11240-012-0171-4

ROCHA, D.I.; MONTE-BELLO, C.C.; DORNELAS, M.C. Alternative induction of de novo shoot organogenesis or somatic embryogenesis from in vitro cultures of mature zygotic embryos of passion fruit (Passiflora edulis Sims) is modulated by the ratio between auxin and cytokinin in the medium. Plant Cell, Tissue and Organ Culture, v.120, n.3, p.1087-1098, 2015. DOI: http://sci-hub.cc/10.1007/ s11240-014-0663-5

ROCHA, D.I.; MONTE-BELLO, C.C.; AIZZA, L.C.B.; DORNELAS, M.C. A passion fruit putative ortholog of the SOMATIC EMBRYOGENESIS RECEPTOR KINASE1 gene is expressed throughout the in vitro de novo shoot organogenesis developmental program. Plant Cell, Tissue and Organ Culture, v.125, n.1, p.107-117, 2016. DOI: http://sci-hub.cc/10.1007/s11240-015-0933-x

ROSA, Y.B.; DORNELAS, M.C. In vitro plant regeneration and de novo differentiation of secretory trichomes in Passiflora foetida L. (Passifloraceae). Plant Cell Tissue and Organ Culture, v.108, n.1, p.91-99, 2012. DOI: http://sci-hub.cc/10.1007/s11240-011-0016-6

SHEKHAWAT, M.S.; KANNAN, N.; MANOKARI, M.; RAVINDRAN, C.P. In vitro regeneration of shoots and ex vitro rooting of an important medicinal plant Passiflora foetida L. through nodal segment cultures. Journal of Genetic Engineering and Biotechnology, v.13, p. 209-214, 2015. DOI: http://sci-hub.cc/10.1016/j. jgeb.2015.08.002 
SILVA, M.L.; PINTO, D.L.P.; GUERRA, M.P.; FLOH, E.I.S.; BRUCKNER, C.H.; OTONI, W.C. A novel regeneration system for a wild passion fruit species (Passiflora cincinnata Mast.) based on somatic embryogenesis from mature zygotic embryos. Plant Cell, Tissue Organ Culture, v.99, n.1, p.47-54, 2009. DOI: http://sci-hub. cc/10.1007/s11240-009-9574-2

SILVA, C.V.; OLIVEIRA, L.S.; LORIATO, V.A.P.; SILVA, L.C.; CAMPOS, J.M.S.; VICCINI L.F.; OLIVEIRA, E.J.; OTONI, W.C. Organogenesis from root explants of commercial populations of Passiflora edulis Sims and a wild passionfruit species, $P$. cincinnata Masters. Plant Cell, Tissue Organ Culture, v.107, n.3, p.407-416, 2011. DOI: http://sci-hub.cc/10.1007/s11240-011-9991-X

SKOOG, F.; MILLER, C.O. Chemical regulation of growth and organ formation in plant tissue cultures in vitro. Symposia of the Society for Experimental Biology, v.11, p.118-131, 1957.
VANDERPLANK, J. 562: Passiflora miniata. Curtis's Botanical Magazine, v.23, n.3, p.223-230, 2006. DOI: htt p://10.1111/j.1467-8748.2006. 00533.x

VIEIRA, L.M.; ROCHA, D.I.; TAQUETTI, M.F.; SILVA, L.C.; CAMPOS, J.M.S.; VICCINI, L.F.; OTONI, W.C. In vitro plant regeneration of Passiflora setacea D.C. (Passifloraceae): the influence of explant type, growth regulators, and incubation conditions. In Vitro Cellular and Developmental Biology-Plant, v.50, n.6, p.738-745, 2014. DOI: http://sci-hub.cc/10.1007/s11627-014-9650-0

VINOD, K.S.; JAYABALAN, N. Regeneration via direct organogenesis from leaf segments of eggplant (Solanum melongena L.). Journal of Plant Sciences, v.10, n.3, p.90-98, 2015. DOI: http://sci-hub.cc/10.3923/ jps.2015.90.98.

XU, L.; HUANG, H. Genetic and epigenetic controls of plant regeneration. Current Topics in Developmental Biology, v.108, p.1-33, 2014. DOI: http://dx.doi. org/10.1016/B978-0-12-391498-9.00009-7 